\title{
Regulation of dorsal in cultured cells by Toll and tube: tube function involves a novel mechanism
}

\author{
Jacqueline L. Norris and James L. Manley \\ Department of Biological Sciences, Columbia University, New York, New York 10027 USA
}

\begin{abstract}
We described previously a transient cotransfection assay that allows us to study regulation of the Drosophila Dorsal protein (dl) in cultured cells. For example, we showed that over-expression of the Toll transmembrane receptor was sufficient to cause relocalization of $\mathrm{dl}$ from the cytoplasm to the nucleus. Here we present data that the tube protein, shown previously by genetic studies to act downstream of Toll, can function in a novel way to enhance $\mathrm{dl}$ activity. In the absence of $\mathrm{dl}$, or when $\mathrm{dl}$ is cytoplasmic, tube is also found in the cytoplasm of transfected cells. But when $\mathrm{dl}$ is localized to the nucleus, so is tube. tube can then function to enhance reporter gene expression, either by cooperation with $\mathrm{dl}$ or as a GAL4-tube fusion protein. tube thus appears capable of acting both as a chaperon or escort for $\mathrm{dl}$ as it moves to the nucleus, and then as a transcriptional coactivator. We also show that the intracytoplasmic domain of Toll, and specifically the region sharing homology with the interleukin-1 receptor, is sufficient to induce dl-tube nuclear translocation.
\end{abstract}

[Key Words: Drosophila; nuclear transport; NF-kB/rel; interleukin-1 receptor]

Received October 31, 1994; revised version accepted December 21, 1994.

The Drosophila Dorsal protein (dl) is a member of the Rel/NF- $\mathrm{K}$ B family of transcription factors that includes several members related to the mammalian protein NF$\mathrm{\kappa B}$ and the avian retrovirus oncogene $\mathrm{v}$-rel (for review, see Gilmore 1991; Blank et al. 1992; Norris and Manley 1994). These proteins share homology over their aminoterminal 300 amino acids, the rel homology domain (RHD). The RHD contains regions important for dimerization, DNA binding and inhibitor binding, as well as a nuclear localization signal (NLS), and a potential protein kinase A (PKA) phosphorylation site (Steward 1987; Ghosh et al. 1990; Kieran et al. 1990; Gilmore 1991; Ip et al. 1991; Isoda et al. 1992; Norris and Manley 1992). The activity of these proteins is regulated by their subcellular localization so that they are inactive when localized in the cytoplasm and activated upon transport into the nucleus (Baeuerle and Baltimore 1988).

Rel/NF- $\mathrm{kB}$ proteins are held in the cytoplasm through their interaction with inhibitor proteins and are transported into the nucleus when this interaction is disrupted in response to external stimuli (for review, see Schmitz et al. 1991). For example, NF-kB is activated by a variety of agents including $B$ - and $T$-cell mitogens, UV light, serum growth factors, double stranded RNA, viral infection, and cytokines such as tumor necrosis factor and interleukin-1 (IL-1) (for review, see Baeuerle and Baltimore 1991). However, the pathways through which all of these agents activate NF- $\mathrm{BB}$ are poorly understood. In contrast, many of the components of the pathway that activates $\mathrm{dl}$ are known and their interactions are begin- ning to be understood. The products of at least 11 genes are required to activate $\mathrm{dl}$ in the early embryo (for review, see Govind and Steward 1991). Their activity results in the establishment of a nuclear concentration gradient of $\mathrm{dl}$ over the embryo with the highest levels present in ventral nuclei and progressively decreasing levels in dorsal nuclei (Rushlow et al. 1989; Roth et al. 1989; Steward 1989). This nuclear gradient of dl is responsible for establishing dorsal-ventral $(D / V)$ polarity in the embryo. The dl protein is uniformally cytoplasmic until cleavage cycle 10 when a ventrally localized signal is generated and transmitted to $\mathrm{dl}$. Six genes function extracellularly to generate this signal, which has been identified as the product of the $\mathrm{D} / \mathrm{V}$ gene spätzle (Stein and Nüsslein-Volhard 1992; Morisato and Anderson 1994). Spatzle appears to serve as the ligand that activates the transmembrane protein Toll, which in turn leads to the activation of $\mathrm{dl}$.

The Toll protein has a large extracellular domain and a small intracytoplasmic domain (Hashimoto et al. 1988; Schneider et al. 1991). The extracellular domain is most similar to the human platelet glycoprotein $1 \mathrm{~b}$ receptor, both of which have leucine and cysteine rich repeats (Lopez et al. 1987; Hashimoto et al. 1988). The intracytoplasmic domain is similar to the cytoplasmic domain of the interleukin 1 receptor (IL-1R) (Schneider et al. 1991). This domain is essential for IL-1R signal transduction (Heguy et al. 1992) and for Toll activity (Schneider et al. 1991; Norris and Manley 1992). The similarities between these two receptors suggest they may activate 
similar signaling pathways. Cells expressing IL-1R can show both an elevation of cAMP levels /Shirakawa et al. 1988) and an increase in an NF-kB-like DNA-binding activity in nuclear extracts (Shirakawa et al. 1989) upon treatment with IL-1. In cultured Drosophila cells the Toll protein can enhance both dl nuclear localization and transcriptional activity through a signaling pathway that utilizes PKA (Norris and Manley 1992).

At least three other genes; tube, pelle, and cactus encode proteins that act downstream of Toll and are essential for regulated nuclear transport of $\mathrm{dl}$. The cactus protein inhibits dl nuclear transport and is similar to the NF- $\mathrm{B}$ inhibitor protein IкB (Geisler et al. 1992; Kidd 1992). Both cactus and $I_{\kappa} B$ contain ankryin repeats, which are thought to aid in cytoplasmic retention through direct protein-protein interactions (Haskill et al. 1991; Geisler et al. 1992; Kidd 1992). The pelle gene encodes a protein kinase that shares homology with the $\mathrm{raf} / \mathrm{mos}$ family (Shelton and Wasserman 1993), although how the protein functions in the activation of $\mathrm{dl}$ is not understood. The protein encoded by the tube gene, which is essential for nuclear transport of $\mathrm{dl}$, shows no homology to any other known protein and the mechanism by which it functions is unknown (Letsou et al. 1991).

We have taken advantage of the fact that regulated nuclear transport of dl can be recapitulated in transfected Schneider cells (Rushlow et al. 1989; Norris and Manley 1992) to investigate further the molecular mechanisms underlying the signaling pathway. Specifically, we have continued our analysis of Toll, as well as investigated the function of the tube protein. We found that expression of Toll's intracytoplasmic domain, specifically the region of Il-1R homology, is sufficient to activate dl. We also show that tube can enhance dl's transcriptional activity, not by enhancing dl nuclear localization but by increasing $\mathrm{dl}$ activity once in the nucleus. Unexpectedly, we found that tube colocalizes with $\mathrm{dl}$. Under conditions where dl was nuclear, tube was also localized in the nucleus, but when dl was localized in the cytoplasm, or not expressed, tube was cytoplasmic. tube thus functions by a novel mechanism, perhaps acting as both a chaperon and coactivator of $\mathrm{dl}$.

\section{Results}

\section{The Toll IL-1R homology is sufficient for Toll activity}

The Toll intracytoplasmic domain is relatively small, consisting of 269 amino acids. It has no known functional homology and is similar to only one other known protein, IL-1R. The cytoplasmic domains of the two receptors are similar over the entire 217 amino acid IL-1R cytoplasmic domain and 200 amino acids of Toll's cytoplasmic domain (Schneider et al. 1991). The Toll cytoplasmic domain contains an additional 68 carboxy-terminal residues that are unique to Toll. Several recessive loss-of-function mutations of Toll result from point mutations within the IL-1R homology (Schneider et al. 1991; Heguy et al. 1992), and a carboxy-terminal deletion in Toll that deletes into the region of IL-1R homology inactivates the protein in transfection assays (Norris and Manley 1992).

To analyze the intracytoplasmic domain of Toll in more detail a more extensive deletion analysis was done. The carboxy-terminal deletions that were analyzed are shown in Figure 1A. The activity of each mutant was determined by testing its ability to enhance dl activity when cotransfected in Drosophila Schneider cells. The activity of $\mathrm{dl}$ was measured by its ability to activate expression of the CAT gene from an $\sim 200$-bp fragment $(-196$ to +39$)$ of the Drosophila zen promoter (zenCAT200; Rushlow et al. 1989; Norris and Manley 1992). Although it is known that zen is naturally repressed by $\mathrm{dl}$ in embryos, this requires a distal repression element not present in zen-CAT200 (Doyle et al. 1989). Although the activity of several promoters lacking apparent $\mathrm{dl}$ binding sites can be enhanced by dl in transfection assays, the strong activation of zen-CAT200 that occurs at high $\mathrm{dl}$ concentrations is likely mediated by a potential weak dl binding site $(-100$ to -91$)$ present in the zen promoter fragment.

We showed previously that coexpression of wild-type Toll can enhance dl activity up to 10-fold (Norris and Manley 1992). Figure $1 \mathrm{~b}$ shows the results of transfecting Act-dl and each of the Act-Toll constructs. Deletions of 90 or more amino acids (Act-TlStul and Act-TlBstU1) resulted in Toll proteins that could no longer activate $\mathrm{dl}$. This was not unexpected as both mutants lack part of the IL-1 R homology. However, deletion of only 60 amino acids (Act-TINac 1), which are unique to Toll, resulted in a protein that was consistently twofold more active than wild-type Toll. This result suggests that Toll contains an additional regulatory domain not found in IL-1R /see Discussion).

Deletion of most of the Toll extracellular domain does not affect Toll activity in Schneider cells (Norris and Manley 1992). We were therefore interested in knowing if the Toll intracytoplasmic domain alone could function in Schneider cells. To investigate this the Toll intracytoplasmic domain, beginning with amino acid 829, was cloned into an Actin 5C expression vector containing the influenza HAl epitope tag (Field et al. 1988; Han and Manley 1993). This construct, Act-TlIC, retained significant activity in Schneider cells, although it was about $50 \%$ less active than wild-type Toll (Fig. 1B). Deletion of the 60 carboxy-terminal Toll unique residues, Act-TlIC$\mathrm{Nae}$, again enhanced activity and resulted in a protein that was as active as wild-type Toll. Therefore, the Toll intracytoplasmic domain alone, and specifically the region similar to Il-1R, is sufficient for activating the signaling pathway that leads to $\mathrm{dl}$ nuclear transport in Schneider cells.

\section{Expression of tube enhances the activity of $d l$}

As mentioned above, the tube protein shares no homology with known proteins, although it contains five repeats of eight amino acids, the tube repeats, in its carboxyl terminus (Letsou et al. 1991). Genetic studies have 
Figure 1. Activity of the Toll cytoplasmic domain. $|A|$ The extracellular and cytoplasmic domains, the region of interleukin 1 receptor homology (IL-1R), and the leucine (LEU)- and cysteine (CYS)-rich regions of the extracellular domain are indicated on wild-type Toll. The regions deleted in the mutants are shown. Numbers refer to amino acid residues. The cytoplasmic domain constructs IC, IC-Nael, and IC-Stu 1 contain the HAl epitope tag (Flu). (B) Schneider cells were cotransfected with 0.4 $\mu \mathrm{g}$ of $\mathrm{dl}$ expression vector, $1.0 \mu \mathrm{g}$ of the zen-CAT200 reporter plasmid, and either pAct5C or the indicated Toll expression vector to bring the final concentration of expression vector to $5.0 \mu \mathrm{g}$. All transfections were normalized for differences in transfection efficiency by using copia $\beta$-gal as an internal control. Fold activation is presented as the increase in CAT activity relative to the value from the cotransfection lacking a Toll expression vector.
A

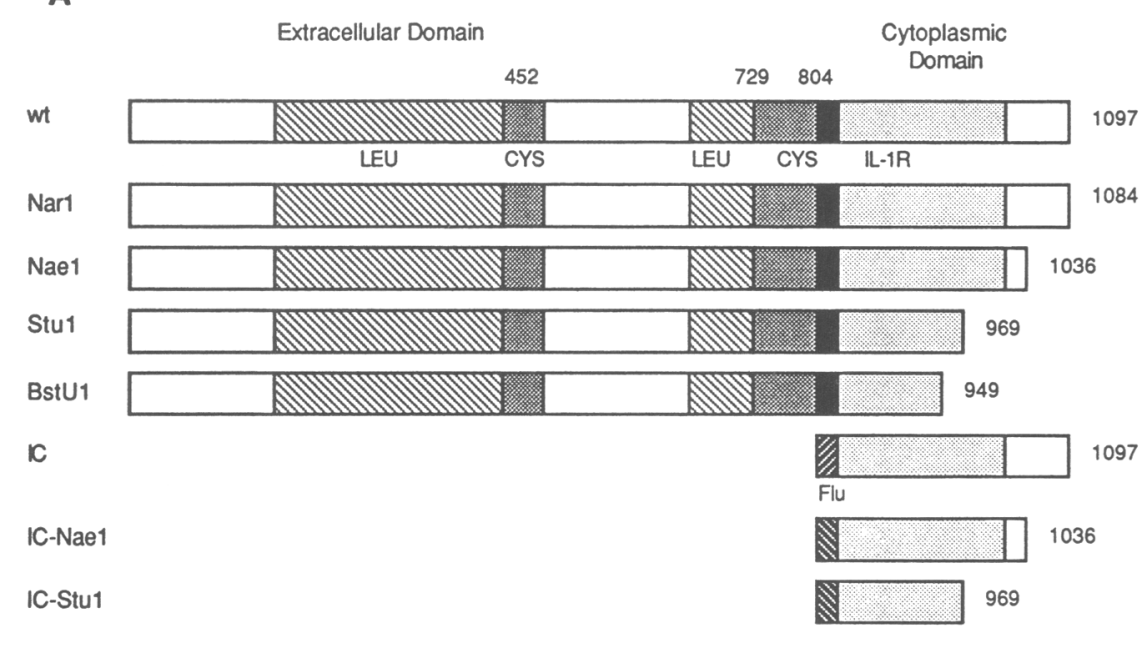

B

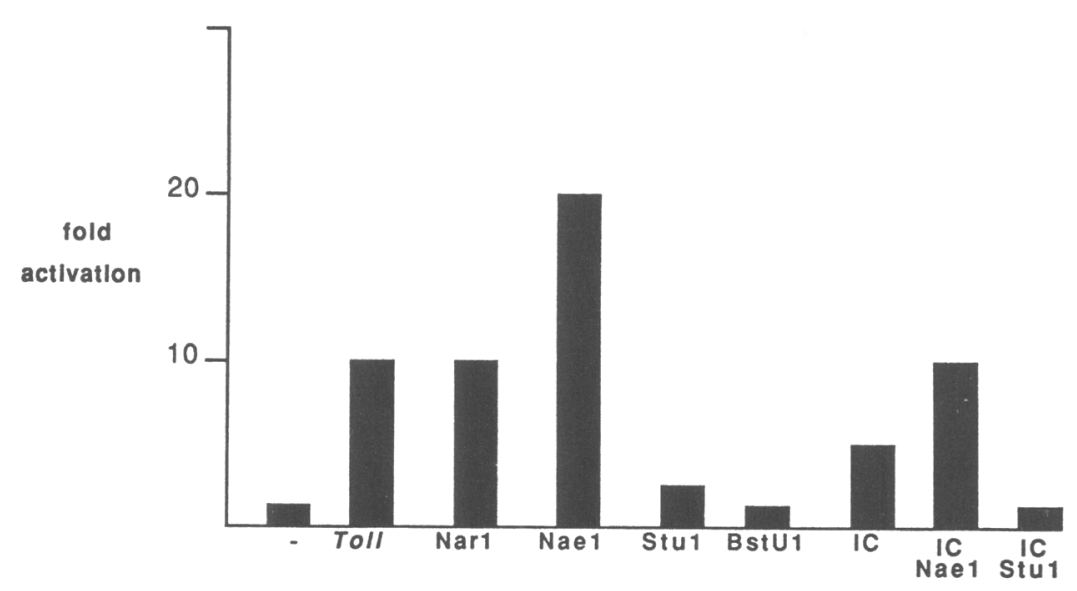

shown that tube acts downstream of Toll (Hecht and Anderson 1993) but its function is unknown. To address tube's role in the signaling pathway for dl nuclear localization, we analyzed the effect of tube expression on the activity of wild-type dl and several mutant derivatives in cotransfected Schneider cells.

Figure 2A shows the tube construct that was used in these experiments. The tube gene was cloned into the Actin $5 \mathrm{C}$ vector containing the influenza virus $\mathrm{HAl}$ epitope tag (Act-tube). Figure $2 \mathrm{~B}$ presents the results of cotransfecting Act-dl, zen-CAT200, and increasing concentrations of Act-tube. At the concentration of $\mathrm{dl}$ expression vector used $(0.4 \mu \mathrm{g}), \mathrm{dl}$ is primarily cytoplasmic, although some cells $(\sim 20 \%)$ do contain detectable nuclear dl (Rushlow et al. 1989; Norris and Manley 1992; see also below). Reflecting at least in part this limited nuclear accumulation, activation induced by $\mathrm{dl}$ in the absence of other factors was low (see Figure legend). However, the CAT activities detected were totally reproducible, and have been observed in large numbers of transfection over several years (e.g., Rushlow et al. 1989; Norris and Manley 1992). Expression of tube enhanced dl's ability to activate CAT expression by up to $\sim 6$-fold at high levels $(6.0 \mu \mathrm{g})$ of Act-tube. The observed activations resulted from a specific functional interaction between $\mathrm{dl}$ and tube, as cotransfection of Act-tube with zen-CAT200 alone did not affect CAT activity (Fig. 2B), nor did cotransfection of Act-tube together with expression vectors encoding other transcriptional activators and their appropriate reporter plasmids /results not shown). The tube activation of $\mathrm{dl}$, directly or indirectly, is dependent on dl's PKA site since expression of tube did not enhance the activity of a dl mutant that contains a glutamine in place of the serine at residue 312 (dlQ). This $\mathrm{dl}$ derivative is more tightly cytoplasmic than wild-type $\mathrm{dl}$ and is also not activated significantly by expression of Toll or PKA (Norris and Manley 1992).

We also analyzed a constitutively nuclear dl mutant, $\mathrm{d} 13$, and found it to be activated nearly 10 -fold by coexpression of tube (Fig. 2B). This dl mutant lacks the 117 carboxy-terminal amino acids, which results in constitutive nuclear localization (Rushlow et al. 1989). dl3 is less active than wild-type $\mathrm{dl}$, but is activated by Toll or PKA at least as well as is wild-type dl (Norris and Manley 


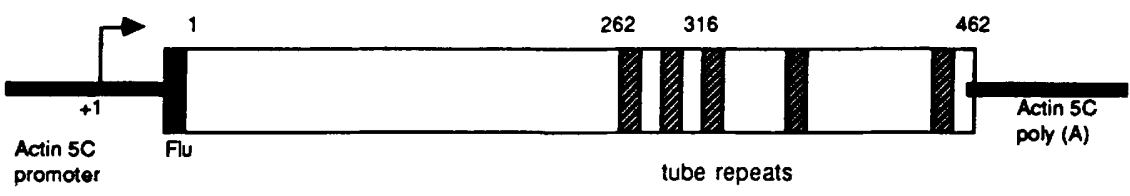

B

Figure 2. The effect of tube on the activity of wild-type and mutant dl. $(A)$ The tube protein contains five repeats of eight amino acids, the tube repeats, in its carboxyl terminus. The Act-tube construct contains the HAl epitope tag (Flu). $(B)$ Schneider cells were cotransfected with 0.4 $\mu \mathrm{g}$ of the indicated $d l$ expression vector, $1.0 \mu \mathrm{g}$ of the zen-CAT200 reporter plasmid, and the indicated amount of tube expression vector. The final concentration of expression vector was brought to $7.0 \mu \mathrm{g}$ with actin $5 \mathrm{C}$ expression vector lacking an insert. The CAT activities shown are expressed relative to cotransfections containing $7.0 \mu \mathrm{g}$ of actin $5 \mathrm{C}$ expression vector without an insert.

1992). Because dl3 is nuclear, its ability to be activated by tube suggests that tube functions in a manner that involves a mechanism in addition to, or distinct from, enhancement of dl nuclear localization.

\section{tube expression does not enhance dl nuclear localization}

Expression of Toll enhances $\mathrm{dl}$ activity in part because it increases the nuclear concentration of $\mathrm{dl}$ (Norris and Manley 1992). To determine whether tube expression was sufficient to enhance $\mathrm{dl}$ nuclear localization, cells were transfected with Act- $d l$ alone or Act- $d l$ plus Acttube, fixed, and stained with anti-dl antibodies. Cells transfected with Act-dl alone produced $\mathrm{dl}$ protein that was localized primarily in the cytoplasm, as described previously (Rushlow et al. 1989; Norris and Manley 1992). Interestingly, the localization of dl did not change upon expression of tube. The percentage of cells with primarily cytoplasmic dl staining remained the same, $\sim 80 \%$, when tube was present (Fig. 3). Therefore, tube does not appear to enhance $\mathrm{dl}$ activity by facilitating an increase in the nuclear concentration of dl. Rather, it likely functions by increasing the activity of the fraction of $\mathrm{dl}$ that is already nuclear. Evidence supporting this view is presented below.

\section{tube is cytoplasmic by itself, but colocalizes with dl}

To gain a better understanding of how tube was able to enhance dl activity, the subcellular localization of exogenously expressed tube was investigated. First, cells were transfected with Act-tube alone, fixed, and stained with anti-flu antibodies. As shown in Figure 4A, tube was localized primarily in the cytoplasm of the trans- fected cells. For comparison, cells were transfected with Act- $-d l$ or Act- $T l$, fixed, and stained with anti-dl or antiToll antibodies. The tube staining pattern was most similar to the dl pattern, uniformally cytoplasmic (Fig. 4B), but unlike the Toll pattern (Fig. 4C). Toll staining appeared as dots or clumps, suggesting aggregation of the protein, likely in the plasma membrane. These staining results suggest that tube was not tightly associated with Toll or the plasma membrane, but localized throughout the cytoplasm.

Next double staining was done to determine the subcellular localization of both tube and $\mathrm{dl}$ when expressed in the same cells. Cells were transfected with Act-tube plus $0.4 \mu \mathrm{g}$ Act $-d l$, fixed, and the proteins detected with anti-dl and anti-flu antibodies. As described above, dl

\begin{tabular}{|c|c|c|c|}
\hline $\begin{array}{c}\text { docrsal } \\
\text { tube }\end{array}$ & cytoplasm & $\begin{array}{c}\text { cytoplasm } \\
\text { and } \\
\text { nucleus }\end{array}$ & nucleus \\
\hline 0 & 76 & 19 & 5 \\
\hline 6.0 & 79 & 18 & 3 \\
\hline
\end{tabular}

Figure 3. Subcellular localization of $\mathrm{dl}$ in the presence of tube. Schneider cells were cotransfected with $0.4 \mu \mathrm{g}$ of $d$ l expression vector and the indicated amounts of tube expression vector $(\mu \mathrm{g})$. Cells were stained with anti-dl and TRITC-conjugated secondary antibodies. At least $50 \mathrm{dl}$-expressing cells from each transfection were counted and scored for staining of the cytoplasm, the nucleus, or both the cytoplasm and nucleus. The percentage of cells in each category is shown. 

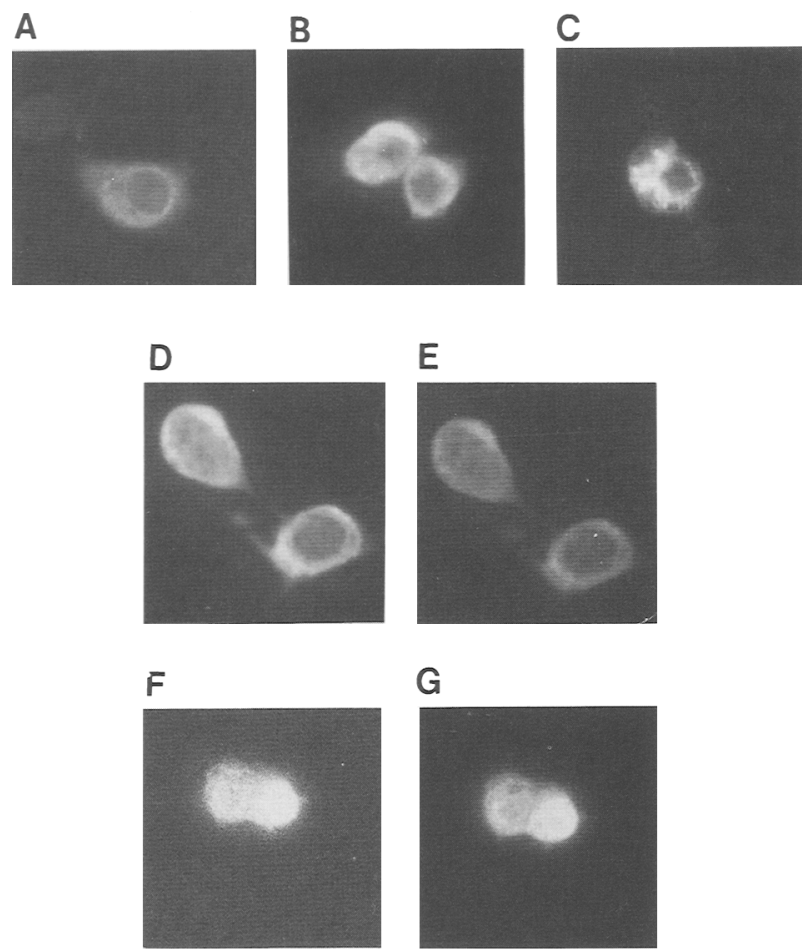

Figure 4. Subcellular localization of tube, dl, and Toll. $|A|$ Schneider cells were transfected with $6.0 \mu \mathrm{g}$ of tube expression vector and stained with anti-flu antibodies and FITC-conjugated secondary antibodies. $(B)$ Schneider cells were transfected with $0.4 \mu \mathrm{g}$ of $d l$ expression vector and stained with anti-dl antibodies and TRITC-conjugated secondary antibodies. (C) Schneider cells were transfected with $5.0 \mu \mathrm{g}$ of Toll expression vector and stained with anti-Toll antibodies and TRITC-conjugated secondary antibodies. $(D-G)$ Schneider cells were cotransfected with $0.4 \mu \mathrm{g}$ of $d l$ expression vector and $6.0 \mu \mathrm{g}$ of tube expression vector. Cells were stained with anti-dl antibodies plus anti-flu antibodies and TRITC-plus FITC-conjugated secondary antibodies. $D$ and $F$ show the dl staining pattern; $E$ and $G$ show the tube staining pattern in the same cell.

was localized primarily in the cytoplasm in most of the transfected cells, although in $\sim 20 \%$ of the expressing cells dl was localized in both nucleus and cytoplasm. Strikingly, in cells with primarily cytoplasmic dl, tube was also found primarily in the cytoplasm (Fig. 4D,E). But when $\mathrm{dl}$ was localized in the nucleus as well as the cytoplasm, tube was also found in both compartments (Fig. 4F,G). These findings suggest that tube colocalizes with dl.

To determine if the subcellular localization of tube was indeed strictly correlated with that of $\mathrm{dl}$, the localization of tube in the presence of several dl mutants was examined. Cells were transfected with Act-tube and each of the dl expression vectors shown in Figure 5A. Figure $5 \mathrm{~A}$ also summarizes the transcriptional activity of each $\mathrm{dl}$ derivative in the presence and absence of tube as well as the localization of both $\mathrm{dl}$ and tube. As mentioned above, and shown in Figure 5B, dl3 was constitutively nuclear. Figure $5 \mathrm{C}$ shows that tube was also local- ized exclusively in the nucleus when expressed with dl3. As shown previously (Norris and Manley 1992), dlQ was localized predominantly in the cytoplasm (Fig. 5D). In the presence of $\mathrm{dlQ}$, tube was also localized principally in the cytoplasm (Fig. 5E). tube also colocalized with most of the other dl derivatives in Figure 5A, including dlD, dlNTS, and dl5 (results not shown). dlREL and tube also colocalized (Fig. 5F,G) indicating that the RHD is sufficient to bring about tube nuclear localization. However, tube was not strictly colocalized with d16. Amino acid residues 245 through 325 were deleted in d16, which resulted in a protein that was localized predominantly in the nucleus (Fig. $5 \mathrm{H}$ ). In the presence of dl6, a fraction of the coexpressed tube protein was also found in the nucleus, but equal or greater levels were consistently detected in the cytoplasm (Figure 5I), indicating that mutation of the RHD can partially uncouple dl-tube colocalization. This result strengthens the suggestion that an interaction involving sequences within the $\mathrm{dl}$ RHD and tube is important for tube nuclear localization.

\section{Expression of tube enhances dl activity in the presence of Toll}

As described above, expression of Toll enhances nuclear localization of $\mathrm{dl}$ and increases $\mathrm{dl}$ transcriptional activity in transfected cells. To determine if tube could further enhance dl activity in the presence of Toll, cells were transfected with Act-dl, the indicated Act-Tl construct, Act-tube, and zen-CAT200. The resulting CAT activities are shown in Figure 6A. All of the Toll constructs tested enhanced dl activity, and coexpression of tube in each case further enhanced activity. Unexpectedly, the highest activations, up to ninefold, were obtained when tube was expressed with the Toll intracytoplasmic domain alone (Act-TlIC and Act-TIICNae). More moderate activations, two- to fourfold, were observed when tube was transfected with the putative membrane-associated Toll proteins.

The subcellular localization of tube and $\mathrm{dl}$ in the presence of Toll was determined as described above. Cells were transfected with Act-dl, Act-TIICNae, and Acttube, fixed and stained with anti-dl and anti-flu antibodies. Figure $6 \mathrm{~B}$ and $\mathrm{C}$ shows that the nuclear localization of both $\mathrm{dl}(\mathrm{B})$ and tube $(\mathrm{C})$ was enhanced by the Toll derivative. To determine if expression of Toll could alter the localization of tube in the absence of $\mathrm{dl}$, cells were cotransfected with Act-Tl10b, a dominant gain-of-function allele with enhanced activity (Norris and Manley 1992), or Act-TlICNae and Act-tube, fixed and stained with anti-flu antibodies. Figure $6 \mathrm{D}$ shows that tube remained primarily cytoplasmic under these conditions. These results show that localization of tube to the nucleus is dependent on the presence of $\mathrm{dl}$ itself, and that although coexpression of Toll can enhance the process, it appears to do so indirectly, by increasing $\mathrm{dl}$ nuclear localization.

\section{Functional domains of the tube protein}

The carboxyl terminus of tube contains the tube repeats, 


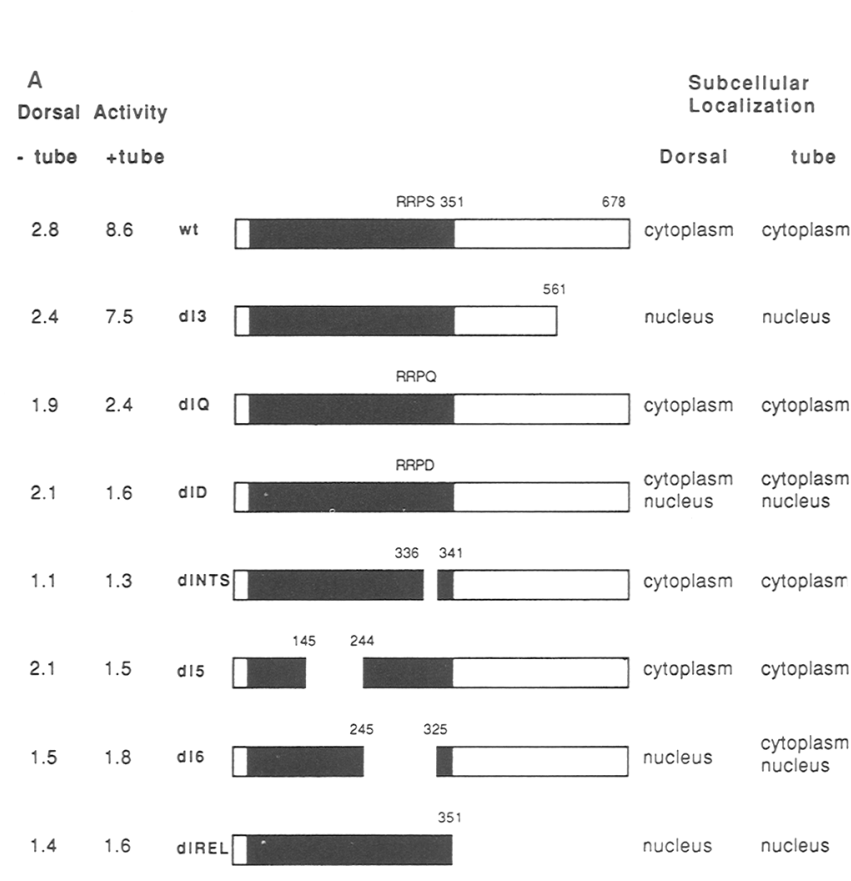

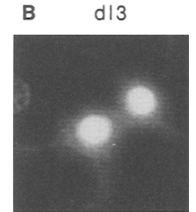
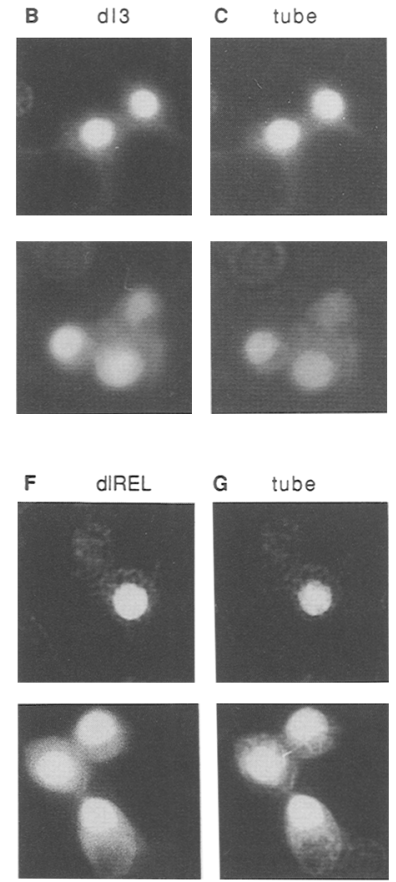
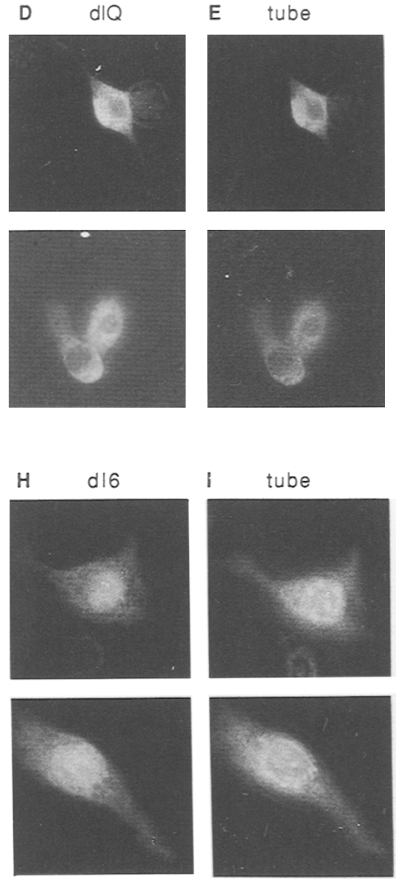

Figure 5. Subcellular localization of tube in the presence of $\mathrm{dl}$ mutants. (A) The region of Rel homology (solid area) and the PKA phosphorylation site (RRPS) are indicated on wild-type dl. The regions deleted and the point mutations in the mutants are shown. Numbers refer to amino acid residues. (Left) CAT activities from Schneider cells transfected with either $0.4 \mu \mathrm{g}$ of the indicated $d l$ expression vector alone (-tube) or plus $6.0 \mu \mathrm{g}$ of the tube expression vector (+tube) and $1.0 \mu \mathrm{g}$ of the zen-CAT200 reporter plasmid. The CAT activities are expressed relative to transfections containing $7.0 \mu \mathrm{g}$ of actin $5 \mathrm{C}$ expression vector without an insert. The predominant location of each protein is indicated at right. $(B-I)$ Schneider cells were transfected with $0.4 \mu \mathrm{g}$ of either $d 13$ expression vector $(B, C), d l Q$ expression vector $(D, E)$, dIREL expression vector $(F, G)$, or dl6 expression vector and $6.0 \mu \mathrm{g} t u b e$ expression vector. Cells were stained with anti-dl plus anti-flu antibodies and TRITC-plus FITC-conjugated secondary antibodies. $(B, D, F, H)$ The dl staining pattern; $(C, E, G, I)$ the tube staining pattern in the same cell. Cells shown are representive of all stained cells from multiple independent transfections.

whereas the amino-terminus is highly conserved between Drosophila melanogaster and Drosophila virilis over $\sim 170$ amino acids (Letsou et al. 1991, 1993). Based on RNA injection experiments, only the amino-terminal 180 amino acids are required to rescue embryos from tube null females (Letsou et al. 1993), suggesting that the tube repeats may by nonessential. To determine the regions of tube required for activity in Schneider cells, constructs were made which express the tube amino terminus (Act-tube $\Delta \mathrm{C}$ ) and carboxyl terminus (Act-tube $\Delta \mathrm{N}$ ) separately (Fig. 7A). Cells were transfected with Act-dl or Act-dl3, Act-tube $\Delta \mathrm{N}$ or Act-tube $\Delta \mathrm{C}$, and zenCAT200, and the resulting CAT activities are presented in Figure 7B. Under these conditions, neither the carboxy- nor the amino-terminal fragments were alone sufficient to enhance dl activity. To determine whether the same were true in the presence of Toll, cells were transfected with Act-dl or Act-dl3, Act-TIICNae, Acttube $\Delta \mathrm{N}$ or Act-tube $\Delta \mathrm{C}$, and zen-CAT200 (Fig. 7B). Under these conditions, tube $\Delta \mathrm{C}$ enhanced dl activity nearly as effectively as full-length tube, whereas tube $\Delta \mathrm{N}$ remained inactive. The possible significance of these results is discussed below.

In addition to these deletions, a tube point mutant, tube2, was also tested for activity in Schneider cells. This mutation results in a single amino acid change of glutamate to lysine at residue 140, which is in the region required for rescue of tube null embryos, and tube 2 is in fact unable to rescue embryos from tube null females in RNA injection experiments (Letsou et al. 1993). To determine the localization and activity of tube 2 it was placed in the actin 5C expression vector (Act-tube2) and cotransfected into Schneider cells with Act-dl. Figure $8 \mathrm{~A}$ shows that tube 2 was unable to enhance the activity of either wild-type $\mathrm{dl}$ or the constitutively nuclear $\mathrm{dl} 3$. However, immunofluorescence showed that tube 2 still colocalized with $\mathrm{dl}$, in the cytoplasm with wild-type $\mathrm{dl}$ (Fig. 8B,C) and in the nucleus with $\mathrm{dl} 3$ (Fig. 8D,E). These results suggest that this mutation affects tube's transcriptional activity and not its ability to co-localize with dl.

\section{A GAL4-tube fusion protein can activate transcription}

Because tube enhances dl's transcriptional activity and is colocalized in the nucleus with $\mathrm{dl}$, tube itself may have the potential to activate transcription. To test this idea, an expression vector (ActG4-tube) containing the tube 
A

\begin{tabular}{|c|c|c|}
\hline tube & tube & tlube \\
\hline Toll & 3.1 & 11.6 \\
\hline 100 & 9.6 & 26.9 \\
\hline Nae1 & 17.3 & 70.3 \\
\hline IC & 5.4 & 47.8 \\
\hline IC Nae1 & 8.7 & 78.6 \\
\hline
\end{tabular}

B

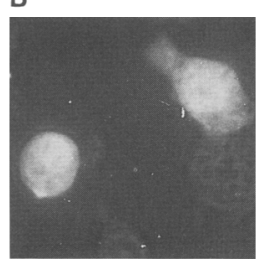

C

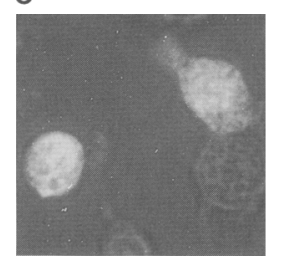

D

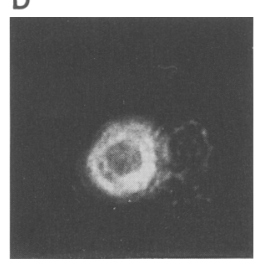

Figure 6. The effect of tube on dl activity in the presence of Toll. $(A)$ Schneider cells were cotransfected with $0.4 \mu \mathrm{g}$ of $d l$ expression vector, $3.0 \mu \mathrm{g}$ of the indicated $T o l l$ expression vector, $1.0 \mu \mathrm{g}$ of the zen-CAT200 reporter plasmid, and $3.6 \mu \mathrm{g}$ of either pAct $5 \mathrm{C}$ (-tube) or tube expression vector (+ tubc). The activation values are expressed relative to cotransfections containing the actin $5 C$ expression vector without an insert. $(B, C)$ Schneider cells were transfected with $0.4 \mu \mathrm{g}$ of $d l$ expression vector, $3.0 \mu \mathrm{g}$ of T/ICNae expression vector, and $3.6 \mu \mathrm{g}$ of $t$ ube expression vector and stained with anti-dl plus anti-flu antibodies and TRITC-plus FITC-conjugated secondary antibodies. Approximantly $75 \%$ of stained cells have perdomaintely nuclear or whole cell staining of $\mathrm{dl}$ and tube. $|D|$ Schneider cells were transfected with $3.0 \mu \mathrm{g}$ of $T 110 \mathrm{~b}$ expression vector plus $4.0 \mu \mathrm{g}$ of tube expression vector and stained with anti-flu antibodies and FITC-conjugated secondary antibodies.

coding region fused to the GAL4 DNA-binding domain was constructed and cotransfected into Schneider cells with a reporter plasmid containing the CAT gene under control of a minimal promoter containing five GAL4 binding sites (G5E1bTATA CAT; Colgan et al. 1993). Figure 9 shows that expression of G4-tube enhanced CAT activity $\sim 3$-fold relative to expression of the GAL4 DNA binding domain alone. Although modest, activation was completely reproducible and entirely dependent on the GAL4 DNA-binding sites (results not shown). In addition, expression of GAL4-tube2 did not activate CAT expression. This result both strengthens the conclusion that the tube2 mutation affects the transcriptional activity of the protein, and at the same time supports the significance of the relatively small activation observed with GAL4-tube. To determine if GAL4-tube transcriptional activity requires the tube amino terminus, two additional GAL4 fusion proteins were made.
ActG4-tube $\Delta \mathrm{N}$ expressed the carboxyl terminus and ActG4-tube $\Delta \mathrm{C}$ expressed the amino terminus. Figure 9 shows that the fusion protein containing the tube amino terminus (G4-tube $\Delta \mathrm{C}$ ) also enhanced CAT expression, in fact somewhat better than full-length tube, whereas the carboxyl terminus (G4-tube $\Delta \mathrm{N}$ ), despite being highly acidic and serine/threonine rich, had no transcriptional activity. These results indicate that the tube protein alone, when tethered to DNA, can enhance transcription, strengthening the view that tube can serve as a coactivator for $\mathrm{dl}$.

\section{Discussion}

We have shown that the intracytoplasmic domain of the transmembrane protein Toll is sufficient for enhancement of dl activity in Schneider cells, and that this region may consist of two functional subdomains. In addition, we have shown that the tube protein, whose function in regulating $\mathrm{dl}$ has been unknown previously, can enhance dl activity in Schneider cells. We have presented evidence for a novel mechanism in which tube enhances dl activity not by simply increasing the nuclear localization of $\mathrm{dl}$ but by translocating directly with $\mathrm{dl}$ into the nucleus. The tube protein may thus function both as a chaperon and coactivator of $\mathrm{dl}$.

\section{Regulation of Toll activity}

As we have discussed previously, we believe that Toll is active in Schneider cells because of overexpression and subsequent aggregation (Norris and Manley 1992). This idea is supported by the immunofluorescence studies reported here, which show that transfected Toll is aggregated around the plasma membrane. The Toll extracellular domain is not required for Toll activity in Schneider cells and the intracellular domain alone is sufficient. The intracellular domains of the Drosophila Notch and Caenorhabditis elegans Lin-12 proteins have been shown to be sufficient for protein activity (Rebay et al. 1993; Struhl et al. 1993). Expression of either truncated Notch or Lin-12 resulted in a gain-of-function phenotype associated with protein activation. Therefore, the intracellular domains have intrinsic activity that is regulated by the extracellular domain in the intact proteins. Toll may behave in a similar manner so that the extracellular domain regulates the activity of the intracellular domain.

There appear to be at least two functional subdomains in the Toll intracytoplasmic domain. The first consists of a region of $\sim 200$ residues that is similar to the IL-1R intracytoplasmic domain. Deletions in this region abolish Toll's ability to enhance dl activity and nuclear localization. The second domain consists of $\sim 60$ residues that are not found in IL-1R, and deletion of this region was found to enhance Toll activity. Therefore, we propose that Toll's intracytoplasmic domain consists of an active domain, responsible for signal transduction, and a regulatory domain. This putative regulatory domain could function to physically mask the active domain, 
A

tube

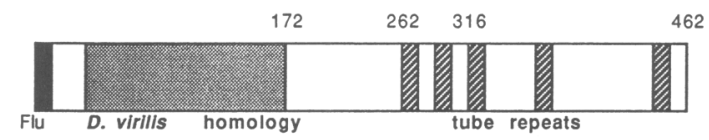

tube $\Delta \mathrm{C}$

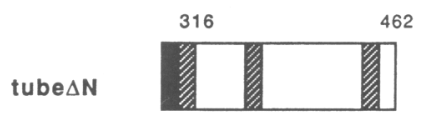

\section{B}
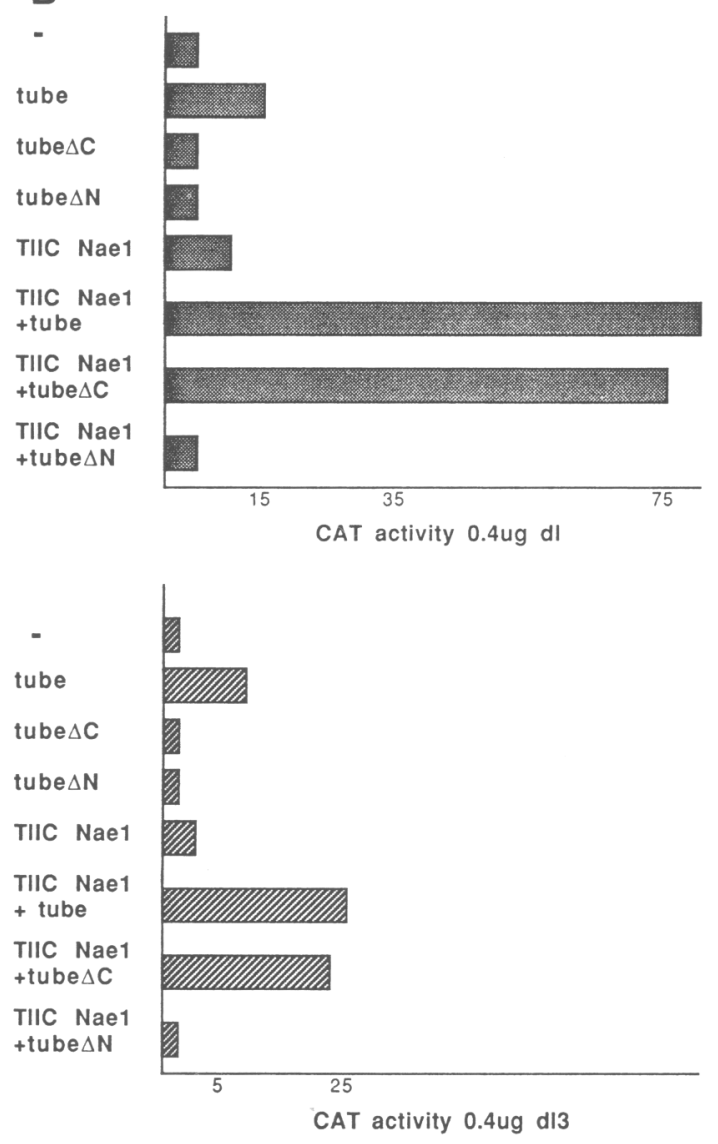

Figure 7. The functional domains of the tube protein. $(A)$ The tube repeats in the carboxyl terminus and the region of homology with the $D$. virilis tube protein in the amino terminus are shown on wild-type tube. The regions deleted in the mutants are shown. Numbers refer to amino acid residues. Each construct contains the HAl epitope tag (Flu). (B) Schneider cells were cotransfected in the combinations shown using the following amounts of expression vector: $0.4 \mu \mathrm{g}$ of the indicated $d l$ expression vector, $3.6 \mu \mathrm{g}$ of the indicated tube expression vector, and $3.0 \mu \mathrm{g}$ of TIICNae. All cotransfections contained $1.0 \mu \mathrm{g}$ of the zen-CAT200 reporter plasmid and pAct5C expression vector to bring the final concentration of expression vector to $7.0 \mu \mathrm{g}$. CAT activity is presented relative to transfections containing $7.0 \mu \mathrm{g}$ of actin $5 \mathrm{C}$ expression vector without an insert. making it inaccessible to other components of the signaling pathway. Activation of Toll, by ligand binding or aggregation, would then result in a conformational change leading to the unmasking of the active domain, allowing it to interact with another component of the signaling pathway. Components of the signaling pathway that interact directly with Toll have not been identified. However, at least in Schneider cells, activation of Toll ultimately leads to activation of PKA (Norris and Manley 1992).

\section{The role of tube in regulating $d l$}

We have shown that expression of tube can enhance $\mathrm{dl}$ activity in Schneider cells. There are several mechanisms, not mutually exclusive, by which tube could activate $\mathrm{dl}$. One possible mechanism would involve an interaction of tube with Toll. In this situation, following Toll activation tube would interact with the intracytoplasmic domain and facilitate transmission of the signal to another component of the pathway. This mechanism seems unlikely because our immunostaining experiments suggest that Toll and tube do not colocalize, and coexpression of the two proteins did not suggest any cooperative interactions. In addition, if tube were responsible for transmitting the signal from Toll to other components of the pathway, then the nuclear localization of dl should be enhanced when tube is expressed.

Another possible mechanism by which tube could function involves transcriptional regulation. In this case tube would enhance $\mathrm{dl}$ activity by acting as a coactivator. This is the case for a component of the NF-kB system, $b c l-3$. The $b c l-3$ gene is an IKB-like protein that has been shown to associate with $\mathrm{p} 50$ homodimers and serve as a transcriptional coactivator (Bours et al. 1993; Franzoso et al. 1993; Fujita et al. 1993). Our results support this type of function for tube because tube colocalizes to the nucleus with $\mathrm{dl}$, enhances the transcriptional activity of a constitutively nuclear dl mutant, and can activate transcription when fused to the GAL4 DNA-binding domain. However, the precise mechanism of action of the two proteins must be distinct, as tube and bcl-3 share no homology.

Embryos containing recessive loss-of-function tube alleles are dorsalized. Given the preceding discussion, this phenotype could result from an inability of these mutant tube alleles to function as transcriptional coactivators. However, tube is required for dl nuclear transport because embryos from females homozygous for mutant tube alleles fail to accumulate nuclear dl (Roth et al. 1989; Steward 1989). In the embryo, one of tube's functions may be to activate pelle in the cytoplasm (Großhans et al. 1994). However, pelle's role in dl nuclear transport in still unclear. Whether tube is essential for nuclear transport of $\mathrm{dl}$ in Schneider cells is also unclear. tube is expressed in Schneider cells (J.L. Norris and J.L. Manley, unpubl.; S. Wasserman, pers. comm.) and so may be necessary for dl nuclear transport in these cells. Alternatively, other components required to regulate $\mathrm{dl}$ nuclear transport, such as pelle, may not be active in 
A

\begin{tabular}{|c|c|c|c|}
\hline torsal & - & tube2 & tube \\
\hline $\mathrm{dl}$ & 4.8 & 5.2 & 19.4 \\
\hline $\mathrm{dl3}$ & 2.3 & 2.5 & 21.2 \\
\hline
\end{tabular}
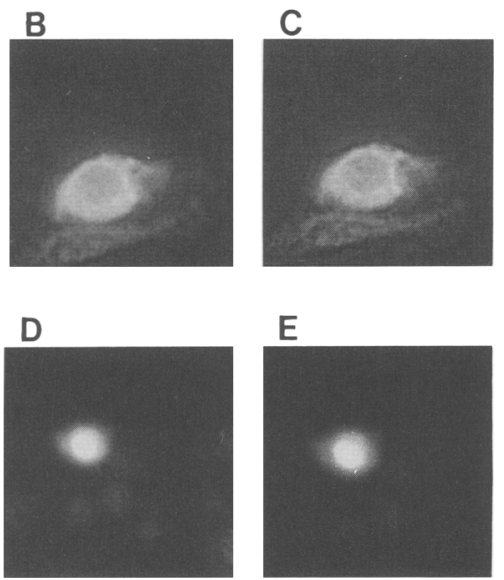

Figure 8. Activity of tube 2 mutant protein. $(A)$ Schneider cells were cotransfected with $0.4 \mu \mathrm{g}$ of the indicated $d l$ expression vector, $1.0 \mu \mathrm{g}$ of the zen-CAT200 reporter plasmid, and either pAct $5 \mathrm{C}(-$ tube 2$)$ or the tube 2 expression vector to bring the final concentration of the expression vector to $7.0 \mu \mathrm{g}$. The CAT activities shown are expressed relative to cotransfections containing $7.0 \mu \mathrm{g}$ of actin $5 \mathrm{C}$ expression vector without an insert. $(B-E)$ Schneider cells were cotransfected with $0.4 \mu \mathrm{g}$ of either wild-type $d l$ expression vector $(B, C)$ or $d l 3$ expression vector $(D, E)$ and $6.0 \mu \mathrm{g}$ of tube2 expression vector. Cells were stained with anti-dl plus anti-flu antibodies and TRITC-plus FITCconjugated secondary antibodies. $(B, D)$ The dl staining pattern; $(C, E)$ the tube2 staining pattern in the same cell.

Schneider cells and so the requirement for tube can be overcome. What is clear is that, in Schneider cells, tube has the ability to translocate to the nucleus together with dl.

A possible role for tube in $\mathrm{dl}$ nuclear transport is to serve as a chaperon for $\mathrm{dl}$. Such a chaperon could have at least two functions. First, tube could bind dl after dissociation of the $\mathrm{dl} /$ cactus complex, thereby preventing reassociation of $\mathrm{dl}$ and cactus. Support for this comes from our analysis of $\mathrm{dl}$ mutants. Deletion of amino acids 245325 results in a protein (dl6) that is localized predominantly in the nucleus. The region around residue 270 has been identified as being required for cactus to interact with dl (Kidd 1992), which suggests that di6 is nuclear because it can no longer interact efficiently with cactus. tube was found in the cytoplasm as well as the nucleus when expressed with dl6, suggesting that this region of $\mathrm{dl}$ also contains sequences required for interaction with tube. Also supporting a role for this region, dlREL, which completely lacks the carboxy-terminal unique region, is fully active in causing colocalization of tube to the nucleus. If tube and cactus can interact with the same region of $\mathrm{dl}$, then the association of $\mathrm{dl}$ with one could prevent association with the other. The interaction of $\mathrm{dl}$ and tube would thus prevent reassociation with cactus and ensure dl nuclear transport. A second, not mutually exclusive, function of $\mathrm{dl} /$ tube association is that it could modulate post-translational modification of $\mathrm{dl}$. Phosphorylation of serine 312 by PKA has been suggested to enhance both nuclear transport and transcriptional activity of dl in Schneider cells (Norris and Manley 1992), and it is known that $\mathrm{dl}$ becomes phosphorylated at multiple sites concomitant with its transport to the nucleus in the embryo (Whalen and Steward 1993; Gillespie and Wasserman 1994). Some dl phosphorylation may be dependent on pelle (Gillespie and Wasserman 1994). In addition, pelle can interact with and phosphorylate tube in vitro (Großhans et al. 1994) suggesting that tube activity may also be regulated by posttranslational modifications. A dorsal/tube interaction could facilitate the modification of one or both proteins and/or prevent inappropriate dephosphorylation.

The amino terminus of tube is required for tube function. The 180 amino-terminal amino acids will rescue tube null embryos, the amino-terminal 316 amino acids enhances dl activity in Schneider cells, and a point mutation within this region, tube 2 , can abolish tube activity in both systems. Results presented here suggest that the tube 2 mutation affects transcriptional activity of tube and not its ability to colocalize with $\mathrm{dl}$. This further supports a role for tube in regulation of transcription in addition to nuclear localization of $\mathrm{dl}$. Although the carboxyl terminus contains the tube repeats, it appears not to be required for regulating $\mathrm{dl}$. This region is rich in acidic and serine and threonine residues suggesting that it could play a role in regulating tube, and may be required later in development when zygotic tube is expressed. This is suggested by our finding that deletion of the tube carboxyl terminus results in a protein that is unable to enhance $\mathrm{dl}$ activity in the absence of Toll but is in its presence. Expression of Toll may thus be able to overcome the requirement for full-length tube, possibly by ensuring the maintenance of $\mathrm{dl}$ phosphorylation. Consistent with this idea, Toll is expressed in the embryo when maternal tube is required, and the amino terminus of tube is sufficient for tube function under these conditions. However, zygotic tube function (i.e., in the absence of Toll) may require the carboxyl as well as the amino terminus.

In summary, the work presented here provides evidence that tube can function in Schneider cells both in $\mathrm{dl}$ nuclear transport and in modulating the transcriptional activity of $\mathrm{dl}$. Two results suggest that tube may function in a related manner in embryos. First, tube can also localize to the nucleus in early embryos (S. Gillespie and S. Wasserman, pers. comm.), raising the possibility that at least part of tube's role in the embryo may involve localization with nuclear $\mathrm{dl}$. Second, as discussed above, 


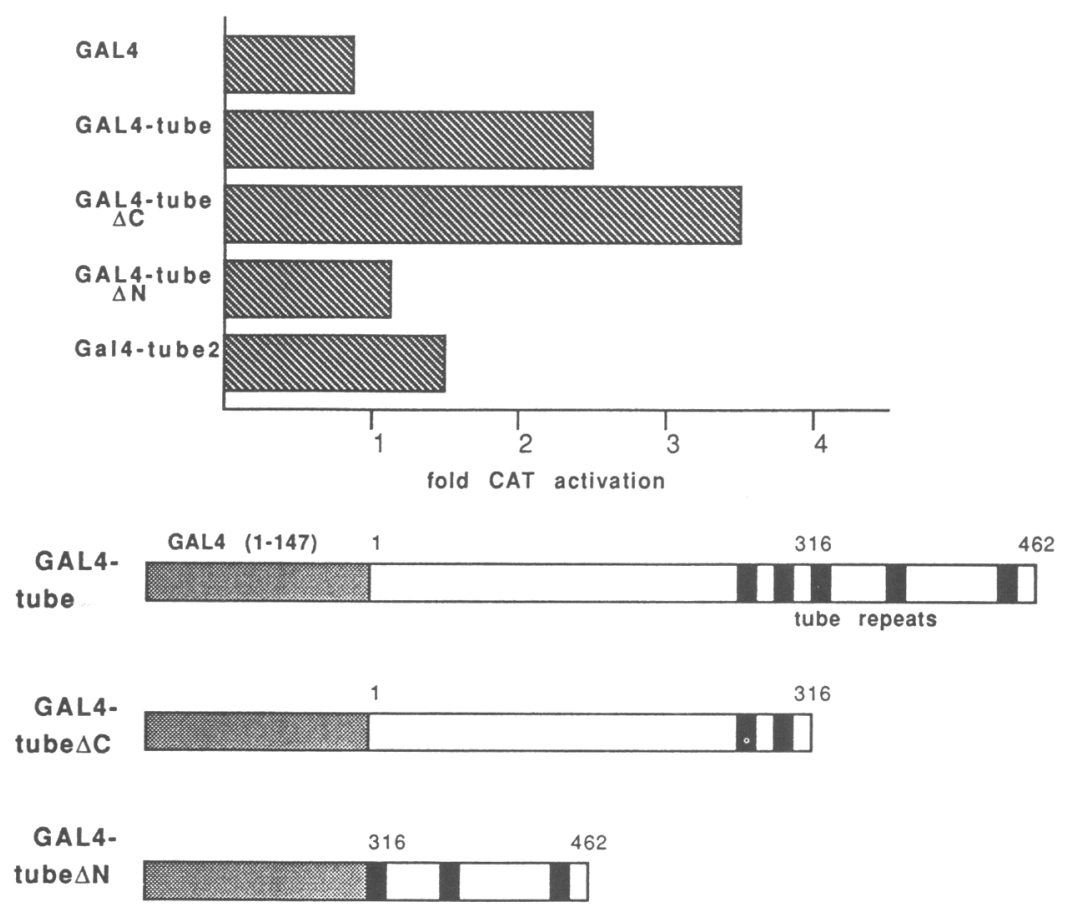

Figure 9. Transcriptional activity of GAL4 tube fusion proteins. The full-length tube protein, both wild type and the tube 2 mutant, as well as amino- and carboxy-terminal fragments were fused to amino acids $1-147$ of the GAL4 DNA-binding domain. Schneider cells were cotransfected with $6.0 \mu \mathrm{g}$ of the indicated GAL4 expression vector and $1.0 \mu \mathrm{g}$ of the G5E1bTATA CAT reporter plasmid, plus the copia-ßgal internal standard and carrier DNA as described,in Materials and methods. Fold activation is presented as the increase in CAT activity relative to the value from the cotransfection containing the GAL4 1-147 expression vector.

the behavior of the tube mutants that we tested in Schneider cells is consistent with the effects of similar mutations in embryos, suggesting that related mechanisms may be involved. Further analysis of the $\mathrm{dl} /$ tube interaction as well as of tube's interactions with other proteins will be required to explain fully tube's role in regulating both dl nuclear transport and transcriptional activity.

\section{Materials and methods}

\section{Recombinant plasmids}

All expression vectors were derived from a plasmid that contains the Drosophila actin 5C promoter and poly $(\mathrm{A})$ site, pAct5C, which has been described in detail (Han et al. 1989). The zen-CAT200 reporter plasmid, pAct-dl, pAct-dl3, pAct$d l \mathrm{Q}, \mathrm{pAct}-d l \mathrm{D}, \mathrm{pAct}-d 15$, pAct-dl6, pAct-dlftz (dl9), and pAct-dINTS (dl7) have been described previously (Rushlow et al. 1989; Norris and Manley 1992). The pAct-dIRHD construct was provided by $\mathrm{K}$. Han (Columbia University, NY).

The pAct- $T$ l, pAct-TlStul, and pAct- $T 1^{10 \mathrm{~b}}$ expression vectors have been described previously (Norris and Manley 1992). The remaining Toll expression vectors were created from the above plasmids by standard cloning and mutagenesis procedures. The actin $5 \mathrm{C}$ expression vector containing the $\mathrm{HAl}$ epitope tag was described previously (pActPflu; Han and Manley 1993).

The pAct-tube expression vector was constructed from a tube cDNA clone kindly provided by $\mathrm{S}$. Wasserman (Letsou et al. 1991). The tube $\Delta C$, tube $\Delta N$, and tube 2 expression vectors were constructed by standard procedures. The tube 2 cDNA was kindly provided by S. Wasserman (Letsou et al. 1993). The pG4tube expression vectors were constructed fragment from the actin $5 \mathrm{C}$ expression vector containing the coding region for the GAL4 DNA-binding domain (pAct-GAL4; Han and Manley 1993).

\section{DNA transfection and transient expression assay}

Drosophila Schneider L2 cells were grown and transfected as described previously (Han et al. 1989). Transfections containing $d l$ and Toll expression vectors contained the indicated amount of each expression vector and variable amounts of pAct5C to bring the total amount of expression vector to $5.0 \mu \mathrm{g}$. Transfections containing $d l, T o l l$, and tube expression vectors contained the indicated amount of each expression vector and variable amounts of pAct5C to bring the total amount of expression vector to $7.0 \mu \mathrm{g}$. All transfections contained $1.0 \mu \mathrm{g}$ of the zenCAT200 reporter plasmid and $2.0 \mu \mathrm{g}$ of the copia long terminal repeat (LTR)-lacZ (copia- $\beta$ gal) plasmid as an internal control. The total amount of DNA in each transfection was brought to $10 \mu \mathrm{g}$ using the pGEMl plasmid. All transfections were performed in duplicate, and $\beta$-galactosidase and CAT activities were measured as described previously (Han et al. 1989). Normalized CAT activities were calculated by determining CAT: $\beta$ gal activity ratios and averaging the values from several independent transfections.

\section{Staining of cells}

Cell staining was performed essentially as described previously (Norris and Manley 1992). Double staining was performed by first incubating fixed cells with the indicated primary antibodies. Cells were then washed three times, and proteins visualized by incubation with the appropriate TRITC- and FITC-conjugated secondary antibodies.

The $\mathrm{dl}$ primary antibodies were prepared by isolating $\mathrm{dl}$ protein expressed from the pAR3040 vector (Rushlow et al. 1989). Purified dl protein was injected into rats (Pocono Rabbit Farms, Canadensis, PA|. An anti-rat TRITC-conjugated secondary antibody (Sigma) was used to visualize the dl staining pattern. The Toll primary antibodies were prepared by isolating a Toll-TrpE fusion protein that contained Toll residues $203-795$. The con- 
struct expressing the fusion protein was made by isolating a 1.7-kb EcoRI-SalI fragment from Act- $T l$ and ligating it with the pATH11 vector (provided by A. Tzagoloff; Koerner et al. 1991) that had been digested with EcoRI and Sall. The resulting fusion protein was expressed and purified as described by Koerner et al. (1991) and injected into rabbits (Pocono Rabbit Farms, Canadensis, PA). An anti-rabbit TRITC-conjugated secondary antibody (Sigma) was used to visualize the Toll staining pattern. The Flu primary antibody (mAb 12CA5) was from a culture supernatant provided by J. Field. An anti-mouse FITC-conjugated secondary antibody was used to visualize the tube staining pattern.

\section{Acknowledgments}

We are grateful to S. Wasserman, K. Han, and J. Colgan for providing plasmids, and to J. Field for providing antibodies. We thank M.E. Lane and J. Koltz for advice and discussion, and S. Wasserman for useful discussion and for communicating results prior to publication. This work was supported by National Institutes of Health grant GM37971.

The publication costs of this article were defrayed in part by payment of page charges. This article must therefore be hereby marked "advertisement" in accordance with 18 USC section 1734 solely to indicate this fact.

\section{References}

Baeuerle, P.A. and D. Baltimore. 1988. Activation of DNAbinding activity in an apparently cytoplasmic precursor of the NF-кB transcription factor. Cell 53:211-217.

. 1991. The physiology of the NF- $\mathrm{kB}$ transcription factor. Hormonal regulation of transcription. Mol. Aspects Cell. Regul. 6: 409-432.

Blank, V., P. Kourilsky, and A. Nd Israël. 1992. Nf-kB and related proteins: Rel/dorsal homologies meet ankryin-like repeats. Trends Biochem. Sci. 17: 135-140.

Bours, V., G. Franzoso, V. Azarenko, S. Park, T. Kanno, K. Brown, and U. Siebenlist. 1993. The oncoprotein Bcl-3 directly transactivates through $\kappa \mathrm{B}$ motifs via association with DNA-binding p50B homodimers. Cell 72: 729-739.

Colgan, J., S. Wampler, and J.L. Manley. 1993. Interaction between a transcriptional activator and transcription factor IIB in vivo. Nature 362: 549-553.

Doyle, H.J., R. Kraut, and M. Levine. 1989. Spatial regulation of zerknüllt: A dorsal-ventral patterning gene in Drosophila. Genes \& Dev. 3: 1518-1533.

Field, J., J.-I. Nikawa, D. Broek, B. MacDonald, L. Rodgers, I.A. Wilson, R. Lerner, and M. Wigler. 1988. Purification of a RAS-responsive adenyl cyclase complex from Saccharomyces cervisiae by use of an epitope addition method. Mol. Cell. Biol. 8: 2159-2165.

Franzoso, G., V. Bours, V. Azarenko, S. Park, M. Tomita-Yamaguchi, T. Kanno, K. Brown, and U. Siebenlist. 1993. The oncoprotein Bcl-3 can facilitate NF- $\mathrm{B}$ mediated transactivation by removing inhibiting $\mathrm{p} 50$ homodimers from select $\kappa \mathrm{B}$ sites. EMBO I. 12: 3893-3981.

Fujita, T., G.P. Nolan, H.-C. Liou, M.L. Scott, and D. Baltimore. 1993. The candidate proto-oncogene $b c l-3$ encodes a transcriptional coactivator that activates through NF-kB p50 homodimers. Genes \& Dev. 7: 1354-1363.

Geisler, R., A. Bergmann, Y. Hiromi, and C. Nüsslein-Volhard. 1992. cactus, a gene involved in dorsoventral pattern formation of Drosophila, is related to the I $\mathrm{B}$ gene family of vertebrates. Cell 71: 613-621.

Ghosh, S., A.M. Gifford, L.R. Riviere, P. Tempst, G.P. Nolan, and D. Baltimore. 1990. Cloning of the p50 DNA binding subunit of NF-kB: Homology to rel and dorsal. Cell 62: 1019-1029.

Gillespie, S.K. and S.A. Wasserman. 1994. dorsal, a Drosophila Rel-like protein, is phosphorylated upon activation of the transmembrane protein Toll. Mol. Cell. Biol. 14: 3559-3568.

Gilmore, T.D. 1991. Malignant transformation by mutant Rel proteins. Trends Genet. 7: 318-322.

Govind, S. and R. Steward. 1991. Dorsoventral pattern formation in Drosophila: Signal transduction and nuclear targeting. Trends Genet. 7: 119-125.

Grosshans, I., A. Bergmann, P. Haffter, and C. Nüsslein-Volhard. 1994. Activation of the kinase Pelle by Tube in the dorsoventral signal transduction pathway of Drosophila embryo. Nature 372: 563-566.

Han, K. and J.L. Manley. 1993. Transcriptional repression by the Drosophila Even-skipped protein: Definition of a minimal repression domain. Genes \& Dev. 7: 491-503.

Han, K., M.S. Levine, and J.L. Manley. 1989. Synergistic activation and repression of transcription by Drosophila homeobox proteins. Cell 56: 573-583.

Hashimoto, C., K.L. Hudson, and K.V. Anderson. 1988. The Toll gene of Drosophila, required for dorsal-ventral embryonic polarity, appears to encode a transmembrane protein. Cell 52: $269-279$.

Haskill, S., A.A. Beg, S.M. Tompkins, J.S. Morris, A.D. Yurochko, A. Johannes-Sampson, K. Mondal, P. Ralph, and A.S. Baldwin. 1991. Characterization of an immediate-early gene induced in adherent monocytes that encodes $I_{\kappa} B$-like activity. Cell 65: 1281-1289.

Hecht, P.M. and K.V. Anderson. 1993. Genetic characterization of tube and pelle, genes required for signaling between Toll and dorsal in the specification of the dorsal-ventral pattern of the Drosophila embryo. Genetics 135: 405-417.

Heguy, A., C.T. Baldari, G. Macchia, J.L. Telford, and M. Melli. 1992. Amino acids conserved in interleukin-1 receptors (IL1Rs) and the Drosophila Toll protein are essential for IL-1R signal transduction. /. Biol. Chem. 267: 2605-2609.

Ip, Y.T., R. Kraut, M. Levine, and C. Rushlow. 1991. The dorsal morphogen is a sequence-specific DNA-binding protein that interacts with a long-range repression element in Drosophila. Cell 64: 439-446.

Isoda, K., S. Roth, and C. Nüsslein-Volhard. 1992. The functional domains of the Drosophila morphogen dorsal: Evidence from the analysis of mutants. Genes \& Dev. 6: 619630.

Kidd, S. 1992. Characterization of the Drosophila cactus locus and analysis of interactions between cactus and dorsal proteins. Cell 71: 623-635.

Kieran, M., V. Blank, F. Logeat, J. Vandekerckhove, F. Lottspeich, O. LeBail, M.B. Urban, P. Kourilsky, P.A. Baeuerle, and A. Israël. 1990. The DNA binding subunit of NF- $\kappa B$ is identical to factor $\mathrm{KBFl}$ and homologous to the rel oncogene product. Cell 62: 1007-1018.

Koerner, T.J., J.E. Hill, A.M. Myers, and A. Tzagoloff. 1991. High-expression vectors with multiple cloning sites for construction of trpE fusion genes: pATH vectors. Methods Enzymol. 194: 477-490.

Letsou, A., S. Alexander, K. Orth, and S.A. Wasserman. 1991. Genetic and molecular characterization of tube, a Drosophila gene maternally required for embryonic dorsoventral polarity. Proc. Natl. Acad. Sci. 88: 810-814.

Letsou, A., S. Alexander, and S.A. Wasserman. 1993. Domain mapping of tube, a protein essential for dorsoventral patterning of the Drosophila embryo. EMBO I. 12: 3449-3458.

Lopez, J.A., D.W. Chung, K. Fujikawa, F.S. Hagen, T. Papayan- 
nopoulou, and G.J. Roth. 1987. Cloning of the $\alpha$ chain of human platelet glycoprotein $1 \mathrm{~b}$ : A transmembrane protein with homology to leucine-rich $\alpha_{2}$-glycoprotein. Proc. Natl. Acad. Sci. 84: 5615-5619.

Morisato, D. and K.V. Anderson. 1994. The spätzle gene encodes a component of the extracellular signaling pathway establishing the dorsal-ventral pattern of the Drosophila embryo. Cell 76: 677-688.

Norris, J.L. and J.L. Manley. 1992. Selective nuclear transport of the Drosophila morphogen dorsal can be established by a signaling pathway involving the transmembrane protein Toll and protein kinase A. Genes \& Dev. 6: 1654-1667.

- 1994. Regulation of the nuclear transport and activity of the Drosophila morphogen Dorsal. In Inducible Transcription (ed. P. Baeuerle), pp. 243-265. Birkhauser, Boston, MA.

Rebay, I., R.G. Fehon, and S. Artavanis-Tsakonas. 1993. Specific truncations of Drosophila Notch define dominant activated and dominant negative forms of the receptor. Cell 74: 319329.

Roth, S., D. Stein, and C. Nüsslein-Volhard. 1989. A gradient of nuclear localization of the dorsal protein determines dorsoventral pattern in the Drosophila embryo. Cell 59: 11891202.

Rushlow, C., K. Han, J.L. Manley, and M. Levine. 1989. The graded distribution of the dorsal morphogen is initiated by selective nuclear transport in Drosophila. Cell 59: 11651177.

Schmitz, M.L., T. Henkel, and P.A. Baeucrle. 1991. Trends Cell Biol. 1: 130-137.

Schneider, D.S., K.L. Hudson, T.-Y. Lin, and K.V. Anderson. 1991. Dominant and recessive mutations define functional domains of Toll, a transmembrane protein required for dorsal-ventral polarity in the Drosophila embryo. Genes \& Dev. 5: 797-807.

Shelton, C.A. and S.A. Wasserman. 1993. pelle encodes a protein kinase required to establish dorsoventral polarity in the Drosophila embryo. Cell 72: 515-525.

Shirakawa, F., U. Yamashita, M. Chedid, and S.B. Mizel. 1988. Cyclic AMP- an intracellular second messenger for interleukin 1. Proc. Nat1. Acad. Sci. 85: 8201-8205.

Shirakawa, F., M. Chedid, I. Suttles, B.A. Pollok, and S.B. Mizel. 1989. Interleukin 1 and cyclic AMP induce $\kappa$ immunoglobulin light-chain expression via activation of an NF-кB-like DNA-binding protein. Mol. Cell. Biol. 9: 959-964.

Stein, D. and C. Nüsslein-Volhard. 1992. Multiple extracellular activities in Drosophila egg perivitelline fluid are required for establishment of embryonic dorsal-ventral polarity. Cell 68: $429-440$.

Steward, R. 1987. Dorsal an embryonic polarity gene in Drosophila, is homologous to the vertebrate proto-oncogene, c-rel. Science 238: 692-694.

- 1989. Relocalization of the dorsal protein from the cytoplasm to the nucleus correlates with its function. Cell 59: $1179-1188$.

Struhl, G., K. Fitzgerald, and I. Greenwald. 1993. Intrinsic activity of the Lin-12 and Notch intracellular domain in vivo. Cell 74: 330-339.

Whalen, A.M. and R. Steward. 1993. Dissociation of the DorsalCactus complex and phosphorylation of the Dorsal protein correlate with the nuclear localization of Dorsal. I. Cell Biol. 123: 523-534. 


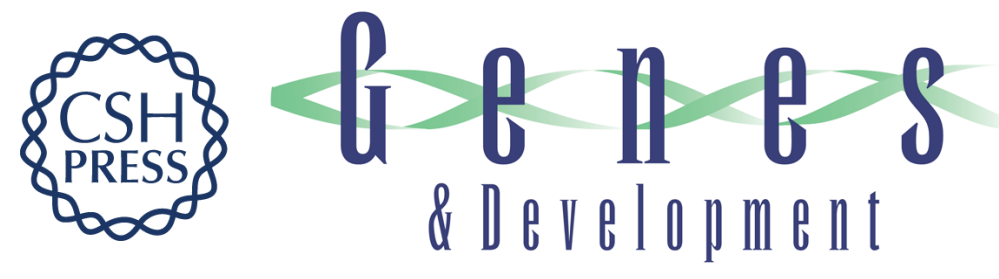

\section{Regulation of dorsal in cultured cells by Toll and tube: tube function involves a novel mechanism.}

$\mathrm{J} L$ Norris and $\mathrm{J} L$ Manley

Genes Dev. 1995, 9:

Access the most recent version at doi:10.1101/gad.9.3.358

References This article cites 44 articles, 16 of which can be accessed free at:

http://genesdev.cshlp.org/content/9/3/358.full.html\#ref-list-1

License

Email Alerting Receive free email alerts when new articles cite this article - sign up in the box at the top Service right corner of the article or click here.

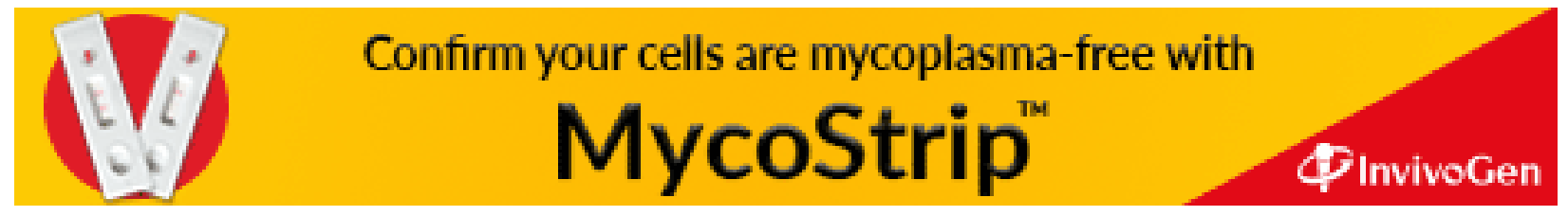

